\title{
Grace Rock's consent
}

\author{
Theodora S Ross
}

Department of Internal Medicine and High-Risk Cancer Program, University of Texas Southwestern Medical Center, 5323 Harry Hines Blvd, Dallas, Texas 75390-8852, USA

(Correspondence should be addressed to T S Ross; Email: theo.ross@utsouthwestern.edu)

Endocrine-Related Cancer (2012) 19 C29-C31

New England leaves changed along with young lives during a fateful September. Grace Rock was 35 years old when she was diagnosed with breast cancer in 1991. As the shock waned, she and her family agreed to participate in a study of cancer-causing mutations conducted by her doctor's hospital.

Grace signed the research consent with urgency. Family members signed in solidarity.

The outcome of the study remained unknown to Grace because 2 years later, she died leaving her husband and two preschoolers. Her death came suddenly. In August 1993, she was everybody's dancing partner at her brother's wedding. A month later, she fell forever silent, surrounded by family in Maine Hospital and an era ended. Or so it seemed.

As with the onset of cancer and its cruel return, the lessons of Grace Rock's consent were unexpected. Among these is the need for defined boundaries between scientists and their subjects. At teaching hospitals, research is the lifeblood of hope. Yet, for patients at these hospitals, the primary medical team has real-time responsibility for care, even if the patients become research subjects of other doctors. In the dawn of the genomic age, when genetic signatures are predicted, by some, to become road maps to sickness and health, the need to separate human investigation from immediate care is crucial. The perils of thinking we know when we don't loom over the future of medicine.

The case arising from Grace Rock's consent reignited in 2001 when Grace's younger sister Tori phoned the research institution. Although the study staff periodically sent vague letters to the family

This essay is based on an actual case. Identifying details have been changed to preserve anonymity for the family. stating no new data linked Grace's cancer to a genetic problem, Tori wanted more definition because she was getting married. 'Ms Rock, your file indicates your family's experience with cancer is not clearly hereditary,' said the voice on the other end who asked her to update her medical history. Tori answered a list of questions indicating that she was a 35-year-old Californian with an uninteresting medical history. She skimmed over the material, signed it, and faxed it back; gratefully noting the onus was on them to keep her informed.

Tori then called Jack, her fiancé. In her desire to put fear behind her, she transposed the words - 'not clearly' to the wishful 'clearly not hereditary.' Subtle denial enabled her to move forward unfettered by genetic worries. Jack, a wannabe scientist, however, reasoned with a laser focus, which regulated Tori's unruly optimism. He insisted genetics might still predispose the Rocks to cancer.

Grace's parents did have cancer histories. Grace's dad was an Ashkenazi Jew who had a string of cancers (e.g. pheochromocytoma and melanoma) before succumbing to lung cancer, even though he was a nonsmoker. His sister died of 'endometrial or ovarian' cancer in her 60s and one of his three brothers died of 'adrenal' cancer at age 50. Grace's mother was a healthy member of a large Polish Catholic family in which only she and a sister were diagnosed with breast cancers in their late $60 \mathrm{~s}$.

At the time of Grace's death in 1993, there were no tests for breast cancer genes. However, in 1994 and 1996, the two mutant genes, BRCAl (Futreal et al. 1994) and BRCA2 (Lancaster et al. 1996, Oddoux et al. 1996), were linked to increased breast and ovarian cancer risk. As Tori and Jack's married life began in 2002 , the data that indicated surgical removal of the 
breasts and ovaries reduced the risk of cancer in women with $B R C A$ mutations was reported (Rebbeck et al. 2002, 2004). These data captured the news cycles. There were several stories about the BRCA discoveries and surgical successes. Tori began to wonder whether Grace would still be alive if she had had prophylactic mastectomies before her 1991 diagnosis.

Tori's married life began 8 years after the aberrant BRCAl gene was linked to cancer. This time lapse enabled Tori and Jack to make a critical assumption: if Grace's DNA encoded a BRCA mutation, surely the Grace's research study would have detected it by now.

The couple put aside their thoughts about Grace's case until just before their second wedding anniversary when Jack noticed a spot on Tori's arm and urged her to consult with a dermatologist-friend, who removed it. A few days later while driving home from her mission bay office, Tori received a cryptic voicemail from the dermatologist requesting another meeting. With a pounding heart, she made a treacherous u-turn at the end of the San Francisco Bay Bridge and drove straight to his office.

The spot was a melanoma, easily treated with minor surgery. No cause for Bay Bridge accidents. Still, the odds of a cancer gene misbehaving in Tori's family had increased - particularly given that Grace had a dark complexion - not somebody who would be expected to develop melanoma at a young age. Jack and Tori, in search of a more information about cancer risk, took a memorable drive along California's Highway 101 to a genetics clinic for a second opinion. Because of her father's Jewish heritage, Grace's cancer and the melanoma, the genetic counselor and oncologist advised Tori to undergo a test for a $B R C A$ mutation. To Tori and the genetic counselor, it seemed unlikely this would be fruitful. Anyway, surely, Grace's research institution would have ruled out aberrant BRCA genes. Nevertheless, blood was sent to the laboratory.

Two weeks later, the counselor called. Tori tested positive for the BRCA1/5385insC mutation, common in Ashkenazi Jews. Tori was surprised and relieved. After years of underlying anxiety, her risky breast and ovarian tissues could now be removed.

Informing family members about the test results was as important as finding great surgeons. Tori and Jack thought each task would be simple. After all, they had concrete news about a malevolent gene. Still, Genetics 101 can be a difficult course. During Sunday dinner with Tori's 82-year-old mother, Julia, an idiosyncratic history professor, Tori and Jack explained the results.
They stated that the mutant BRCAl that killed Grace came from her father. Julia, however, was convinced the bad gene had come from her. As Tori and Jack debated her, Julia suddenly remembered a letter from Grace's research institution promising new information. 'I just filed it away' said Julia. 'It must not have been important or they'd have re-contacted me.' In a quiet voice, Jack asked his mother-in-law for the letter.

Dated 2 years earlier during a time when her husband was in hospice for terminal cancer, the letter was innocuous and vague, relaying only that the research study had new information that they could share if Julia contacted them. Because Julia received the letter when facing the loss of her husband of 50 years, Tori understood why her mother had filed it away.

The next morning, Tori phoned the research institution and explained the sequence of events. After checking their files, staffers apologized for the mistake. They had, indeed, discovered the BRCAl/ 5385ins $C$ mutation 2 years earlier. Tori and Jack re-read with line-by-line acuity their copies of the consent forms for Grace's study. Indeed, the institution promised to inform each Rock of new data that could influence their medical care. Tori requested the staff surrender the family's file by overnight delivery.

Stunned, Tori and Jack wondered what might have changed if they had known about the mutation sooner. If Tori had breast or ovarian cancer, would earlier removal be beneficial? Had similar oversights happened to other families in the study? Did anybody die? Would their medical decisions change? The implications of Grace's consent form betrayal were overwhelming.

The Rocks were fooled by Grace's study because they thought it guaranteed them a continual flow of cutting edge information to influence their medical care. The intermittent bland letters from the researchers diverted them. They thought that it was unnecessary to discuss these issues with other doctors - it was already under study and under control.

Even immediate plans were impacted by the information in the family's file. As Tori poured over it, she was surprised to find that the Ashkenazi Jewish BRCA1 mutation did come from her Polish Catholic mother. Such is the hidden meaning of genes. Although the paternal Jewish heritage originally made more sense, Tori and Jack had not considered the possibility that Julia's side of the family was among the 'Hidden Jews of Poland.' This information was a key piece of the Julia puzzle. These data not only indicated that Julia was at a high risk for cancer but also that 
she came by her 'Jewish Mother' instincts honestly. Tori and Jack switched gears and notified maternal relatives.

Tori successfully managed her risk with prophylactic mastectomies and oophorectomies. One brother was relieved to learn that neither he nor his children carry the BRCAl mutation. Grace's 21-year-old daughter tested positive for BRCA1/5385insC and is being observed by her doctor. She has the opportunity to manage her cancer risk in ways her mom never had.

Tori was freed by the discovery of the $B R C A$ mutation and grateful to the prophylactic surgeries. Her decision was made with the guidance of professionals who were supported by a decade of research demonstrating prophylactic surgeries help patients with BRCA mutations (Rebbeck et al. 2002, 2004). It has taken another decade to convince doctors in the wider community about the benefits of this radical intervention.

In fact, even in 2012, there are physicians who still do not know how to get a $B R C A$ test or what to do with the result. The hope that a 'cheap' $\$ 1000$ genome sequence is going to quickly change how we care for our patients is wishful thinking. Grace's story illustrates the recurring human approach of hope, hype, and 'oops, now what do we do?'

In the case of cancer prevention, timing can be the difference between life and death. For Grace, the time came and went. For Tori, delayed knowledge of the $B R C A$ mutation still proved timely. If she and Jack had not heeded the warning of the melanoma, further delays might have been fatal.

Today, Tori Rock is among many who are alive and thriving because patients like Grace consented to participate in research. Upcoming generations will continue to benefit from research as the tsunami of information from genome sequencing connects to the clinic. The impact of counselors and doctors on the patient's present choices remain critical and their supreme challenge is to advise patients about their genetics in a timely and beneficial way. Patients enrolled in research must understand that study results are unlikely to help them. Instead, they consent with the hope of unlocking potent secrets of the past to improve the future.

\section{Declaration of interest}

The author declares that there is no conflict of interest that could be perceived as prejudicing the impartiality of the research reported.

\section{Funding}

$\mathrm{T}$ S Ross receives support from the Burroughs Wellcome Fund (Clinical Scientist Award) and the National Cancer Institute (R01 CA82363-03, R01 CA098730-01), and holds the Jeanne Ann Plitt Professorship in Breast Cancer Research at UT Southwestern Medical Center.

\section{Acknowledgements}

'Grace Rock's consent' is dedicated to the memory of Myra Kraft, a friend who struggled bravely with ovarian cancer and died 20 July 2011. An engaged philanthropist, Myra, whose family owns the New England Patriots, gave her all to Jewish and humanitarian causes. Her legacy endures in the resilience, vigor and unquenchable optimism of every patient and family member living with cancer.

\section{References}

Futreal PA, Liu Q, Shattuck-Eidens D, Cochran C, Harshman K, Tavtigian S, Bennett LM, Haugen-Strano A, Swensen J, Miki Y et al. 1994 BRCA1 mutations in primary breast and ovarian carcinomas. Science 266 120-122. (doi:10.1126/science.7939630)

Lancaster JM, Wooster R, Mangion J, Phelan CM, Cochran C, Gumbs C, Seal S, Barfoot R, Collins N, Bignell G et al. 1996 BRCA2 mutations in primary breast and ovarian cancers. Nature Genetics 13 238-240. (doi:10.1038/ng0696-238)

Oddoux C, Struewing JP, Clayton CM, Neuhausen S, Brody LC, Kaback M, Haas B, Norton L, Borgen P, Jhanwar S et al. 1996 The carrier frequency of the BRCA2 6174delT mutation among Ashkenazi Jewish individuals is approximately $1 \%$. Nature Genetics 14 188-190. (doi:10.1038/ng1096-188)

Rebbeck TR, Lynch HT, Neuhausen SL, Narod SA, Van't Veer L, Garber JE, Evans G, Isaacs C, Daly MB, Matloff E et al. 2002 Prophylactic oophorectomy in carriers of BRCA1 or BRCA2 mutations. New England Journal of Medicine 346 1616-1622. (doi:10.1056/NEJMoa012158)

Rebbeck TR, Friebel T, Lynch HT, Neuhausen SL, van't Veer L, Garber JE, Evans GR, Narod SA, Isaacs C, Matloff E et al. 2004 Bilateral prophylactic mastectomy reduces breast cancer risk in BRCA1 and BRCA2 mutation carriers: the PROSE Study Group. Journal of Clinical Oncology 22 1055-1062. (doi:10.1200/JCO. 2004.04.188)

Received in final form 7 June 2012 Accepted 11 June 2012 Made available online as an Accepted Preprint 12 June 2012 